Bangladesh J. Zool. 42(2): 211-216, 2014

\title{
EFFECT OF COFFEE ON THE GROWTH AND DEVELOPMENT OF THE RED FLOUR BEETLE, TRIBOLIUM CASTANEUM (HERBST) (COLEOPTERA: TENEBRIONIDAE)
}

\author{
Md. Mostakim and Ataur Rahman Khan* \\ Department of Zoology, University of Rajshahi, Rajshahi-6205, Bangladesh.
}

\begin{abstract}
Effect of various concentrations of coffee, Coffea arabica, viz. 12.50\%, $25 \%$ and $50 \%$ on the growth and development of the red flour beetle, Tribolium castaneum (Herbst) was determined. Coffee lengthened the larval and pupal periods significantly. There was also a significant reduction in the pupal recovery and adult emergence of the beetle following treatment. The food with $50 \%$ coffee had the most detrimental effects on the beetle. Coffee extract could be used as useful botanical pesticide for controlling red flour beetle.
\end{abstract}

Key words: Coffee, Tribolium castaneum, growth, development.

\section{INTRODUCTION}

The red flour beetle, Tribolium castaneum (Herbst) is a major pest of stored food grains and is cosmopolitan in distribution (Good 1933). Both adults and larvae are able to exploit a wide variety of stored commodities (Ziegler 1977). Their presence in the stored products results in both contamination and substantial economic damage due to loss of the product's market price and decreased nutritional value (Burkholder and Faustini 1991). This species has had a long association with human stored food and has been found in association with a wide range of commodities including grain, flour, peas, beans, cacao, nuts, dried fruits, and species, but milled grain products such as flour appear to be their preferred food (Good 1936). Protection of grains, stored for food as well as seed, from the attack of insect pests without imparting toxic effect to human beings and other animals is desirable.

Pest control is a major concern in agriculture and horticulture growers for under developed agro-based countries (Ahmed et al. 2009). The red flour beetle is a common and the most vicious pest among important stored -product insect pests all over the world (Pranoto et al. 1991). It has been reported that the germ part (embryo portion) of the grain is destroyed by $T$. castaneum. Their presence in grain type stored foods directly affects both the quantity and quality of the commodity (Sagheer et al. 2011, Okonkwo and Okoye 1996, Rahman et al. 2011).

*Deceased, Obituary noted in this volume. 
Farmers use various synthetic insecticides and fumigants to control pests, which have serious effects on environment, including pest resistance to pesticides, pest revival, and lethal on the non-target organisms.

Botanical insecticides are considered as an alternative to the synthetic chemicals for being biodegradable, pest specific, non-hazardous to human health and environment and leaving no toxic residue in nature (Farhana et al. 2006, Periera and Wohlgemuth 1982). The present work was aimed at studying the effect of coffee on the growth and development of $T$. castaneum, which seemed important from the point of nutritional regulation of the pest.

\section{MATERIAL AND METHODS}

Adults of $T$. castaneum were collected from the stock culture of the Department of Zoology, Rajshahi University. A large number of beetles were put on a thin film of whole meal flour previously passed through a 60 micrometer mesh sieve in a beaker for egg collection. Eggs were collected by sieving the flour and were incubated at $29 \pm 2{ }^{\circ} \mathrm{C}$ in a Petri dish for hatching of the larvae. Fresh wheat flour mixed with brewer's yeast powder (19:1) were used as experimental food media. Twelve plastic bottles each with $50 \mathrm{gm}$ of the food media were taken and marked as groups 1-4, each having 3 bottles. Bottles of group 1, was used as untreated control, i.e. no coffee was added, respectively. In each bottles of group 2-4, 12.5, 25 and 50\% coffee (by weight) was added. About 30 newly hatched larvae were distribution in each bottle. Each plastic bottle was covered with a piece of cloth and kept at room temperatures of $29 \pm 2^{\circ} \mathrm{C}$.

Growth of the larvae was assessed at two stages: 10 days after treatment cleaned at maturity (18-day old). Ten day old larvae were collected by sieving, washed from adhered flour particles and were weighed (three larvae at a time because of their lower weight) on an electronic balance (ADAM, Japan). Similarly, mature larvae were collected and individually weighed. The larval period was noted and freshly formed pupae were weighed and counted, and placed in separate Petri dishes for adult emergence. The pupal period was recorded. Freshly eclosed adults were weighed and counted for each food. The co-efficient of variation (CV) and growth indices (G.I.s) of T. castaneum at different treatments were calculated. Growth indices (G.I.s) of T. castaneum on different food media were also calculated. The following formula was used for calculating the growth index (Saxena 1969).

G.I. $=\frac{\text { Adult recovery }(\%)}{\text { Total larval and pupal periods }}$ 


\section{RESULTS AND DISCUSSION}

The perusal of data reveals that coffee reduced the growth and development of $T$. castaneum in the following order: wheat flour (control) $>12.5 \%$ coffee $>25 \%$ coffee $>50 \%$ coffee, as shown by analysis of variance (Tables $1 \& 2$ ). Again, coffee significantly reduced the pupal recovery and adult eclosion (\%) of $T$. castaneum in the same order (Table 3). Coffee also distorted the typical sex ratio of $1: 1$ in favour of the females except control (Table 3). Mukherjee and Ramachandran (1989) observed that Azadirachta indica incorporated in wheat flour reduced the growth and survival of $T$. castaneum larvae. Similar results were obtained by Jilani et al. (1988) who reported the significant reduction of body weight of $T$. castaneum larvae, pupae and adults by turmeric, sweet flag and neem oil. The toxic effect of caffeine and castor oil to $T$. castaneum adults and larvae has been reported by Mondal and Akhtar (1992).

Table 1. Effect of coffee on the growth of Tribolium castaneum larvae

\begin{tabular}{lllllll}
\hline \multirow{2}{*}{ Food media } & \multicolumn{7}{c}{ Mean weight \pm SD $(\mathrm{mg})$} \\
\cline { 2 - 7 } & $\begin{array}{l}\text { 10-day } \\
\text { old larvae }\end{array}$ & $\begin{array}{l}\text { Mature } \\
\text { larvae }\end{array}$ & $\begin{array}{l}\text { Pupae } \\
\text { (male) }\end{array}$ & $\begin{array}{l}\text { Pupae } \\
\text { (female) }\end{array}$ & $\begin{array}{l}\text { Adults } \\
\text { (males) }\end{array}$ & $\begin{array}{l}\text { Adults } \\
\text { (females) }\end{array}$ \\
\hline Control & $3.10 \pm 0.38$ & $3.31 \pm 0.41$ & $2.67 \pm 0.43$ & $2.86 \pm 0.29$ & $2.37 \pm 0.31$ & $2.65 \pm 0.18$ \\
$12.5 \%$ coffee* & $2.38 \pm 0.28$ & $2.83 \pm 0.41$ & $2.32 \pm 0.39$ & $2.44 \pm 0.33$ & $2.04 \pm 0.36$ & $2.12 \pm 0.31$ \\
$25 \%$ coffee & $1.95 \pm 0.35$ & $2.36 \pm 0.43$ & $2.18 \pm 0.27$ & $2.29 \pm 0.29$ & $2.00 \pm 0.33$ & $2.08 \pm 0.38$ \\
$50 \%$ coffee & $1.30 \pm 0.22$ & $2.29 \pm 0.35$ & $2.03 \pm 0.28$ & $2.12 \pm 0.30$ & $1.66 \pm 0.26$ & $1.73 \pm 0.26$ \\
\hline F-value & $82.35^{* * *}$ & $41.86^{* * *}$ & $17.96^{* * *}$ & $32.03^{* * *}$ & $25.07^{* * *}$ & $49.62^{* * *}$ \\
\hline
\end{tabular}

*Note: *** Highly significant at $\mathrm{P}=0.00187 .50 \%$ control food (wheat flour+ yeast, $19: 1)+12.50 \%$ coffee and so on.

Table 2. Effect of coffee on the development of Tribolium castaneum larvae

\begin{tabular}{lcccccccc}
\hline & \multicolumn{2}{l}{ Larval period } & \multicolumn{5}{c}{ Pupal period } \\
\cline { 2 - 8 } Food media & No. & Mean \pm SD & $\begin{array}{l}\text { C.V. } \\
(\%)\end{array}$ & t-value & No. & Mean \pm SD & $\begin{array}{l}\text { C.V. } \\
(\%)\end{array}$ & t-value \\
\hline Control & 337 & $18.93 \pm 0.42$ & 2.22 & - & 321 & $7.83 \pm 0.46$ & 5.87 & - \\
$12.5 \%$ coffee* & 265 & $22.06 \pm 0.98$ & 4.44 & -3.64 & 238 & $8.46 \pm 0.82$ & 18.38 & -1.05 \\
$25 \%$ coffee & 247 & $23.61 \pm 0.28$ & 1.18 & -15.70 & 234 & $9.29 \pm 0.32$ & 3.44 & -3.03 \\
$50 \%$ coffee & 226 & $25.72 \pm 0.46$ & 1.79 & -27.85 & 186 & $11.22 \pm 0.33$ & 2.94 & -6.84 \\
\hline
\end{tabular}

*Note: $87.50 \%$ control food (wheat flour+ yeast, 19:1)+12.50\% coffee and so on.

The percentage of adult emergence is an important factor for further infestation. The highest adult emergence indicates the highest infestation. In the present investigation it was found that due to the effect of coffee adult emergence was significantly decreased which is a very much promising aspect to control this pest through nutritional regulation. 
Table 3. Effect of coffee on the sex ratio, pupal recovery and adult emergence (\%) and growth index of Tribolium castaneum

\begin{tabular}{llllllll}
\hline Food media & $\begin{array}{l}\text { Male } \\
(\%)\end{array}$ & $\begin{array}{l}\text { Female } \\
(\%)\end{array}$ & $\begin{array}{l}\text { Male: } \\
\text { female }\end{array}$ & $x^{2}$ Value & Pupae (\%) & Adults (\%) & $\begin{array}{l}\text { Growth } \\
\text { index }\end{array}$ \\
\hline Control & 51.04 & 48.96 & $1: 0.96$ & 0.14 & 93.61 & 89.17 & 3.33 \\
$12.5 \%$ coffee & 46.04 & 53.96 & $1: 1.17$ & 1.66 & 73.61 & 66.11 & 2.17 \\
$25 \%$ coffee & 46.96 & 53.04 & $1: 1.13$ & 0.91 & 68.61 & 65.00 & 1.97 \\
$50 \%$ coffee & 47.79 & 52.21 & $1: 1.09$ & 0.44 & 62.78 & 51.67 & 1.40 \\
\hline
\end{tabular}

*Note: $87.50 \%$ control food (wheat flour+ yeast, $19: 1)+12.50 \%$ coffee and so on.

The pesticidal property of coffee has been documented by a number of researchers. Caffeine (an alkaloid of the methylxanthine family) is naturally produced by a number of plant species, including coffee, tea, mate and guarana (Ashihara and Crozier 2001). Caffeine acts as a chemical defense in these plants, showing repellent or toxicant properties. The first direct evidence of caffeine acting as an insecticide was reported in tobacco hornworm, Manduca sexta larvae (Nathanson 1984), at caffeine concentrations similar to those found in coffee seeds (i.e., 0.8-1.8 wt\%). Caffeine aqueous solutions (2.0 wt \%) have also shown molluscicidal activity against the slug, Veronicella cubensis and orchid snail, Zonitoides arboreous (Hollingsworth et al. 2002, 2003). Other pesticide applications of caffeine include fungi control (Arora and Ohlan 1997), bird repellent (Avery et al. 2005, Linz et al. 2006) and pest coyotes control (Johnston, 2005). A report was obtained for the resistance of coffee seeds to the berry borer, Hypothenemus hampei (Guerreiro and Mazzafera 2003). Caffeine produced high mortality in the fruit fly, Drosophila melanogaster (Nigsch et al. 1977, Zimmering et al. 1977) and the moth fly, Telmatoscopus albipunctatus (Sengal et al. 1977). It also significantly slowed down the growth and development of the latter species. Caffeine inhibits oviposition and delayed development of the shot-hole borer beetle, Xyleborus fornicatus (Hewavitharanage et al. 1999). Studies on $D$. prosaltans demonstrated a series of deleterious biological effects (Itoyama and Bicudo 1992, 1997), which lead to the suggestion of caffeine's usefulness as an alternative insect control method. Coffee also significantly reduced the population of adults, a finding corroborating with that obtained by Itoyama et al. (1992) in D. prosaltans. Higher concentrations of used coffee grounds induced very high larval mortality of Ochlerotatus notoscriptus (Derraik and Slaney, 2005). Caffeine and used coffee grounds completely checked the development of Aedes aegypti at the early stages in treatments with the concentrations 1.0 and $50 \mathrm{mg} / \mathrm{ml}$ respectively (Laranja et al. 2003).

Perusal of the data shows that coffee produced detrimental effects on all the biological parameters of $T$. castaneum. It could be suggested that caffeine may 
prove to be a successful botanical pesticide for the management of the red flour beetle and other storage pests.

Acknowledgements: The authors are most grateful to Professor Dr. A. S. M. Shafiqur Rahman, Chairman, Department of Zoology, University of Rajshahi for providing the necessary laboratory facilities. They are thankful to Professor Dr. Nurul Islam of the department for his interest in this research work.

\section{LITERATURE CITED}

AHMED, B. I., ONU, I. and MUDI, L. 2009. Field bioefficacy of plant extracts for the control of post flowering insect pests of cowpea (Vigna unguiculata L. Walp) in Nigeria. J. Biopestic. 2: 37-43.

ARORA, D. S. and OHLAN, D. 1997. In vitro studies on antifungal activity of tea (Camellia sinensis) and coffee (Coffea arabica) against wood-rotting fungi. J. Basic Microbial. 37: 159-165.

ASHIHARA, H. and CROZIER, A. 2001. Caffeine: A well known but little mentioned compound in plant science. Trends Plant Sci. 6: 407-413.

AVERY, M.L., WERNER, S.J., CUMMINGS, J.L., HUMPHREY, J.S., MILLESON, M.P., CARLSON, J.C., PRIMUS, T.M. and GOODALL, M.J. 2005. Caffeine for reducing bird damage to newly seeded rice. Crop Prot. 24: 651-657.

BURKHOLDER, W.E. and FAUSTINI, D.L. 1991. Biological methods of servey and control. In: Ecology and management of food industry pests. Pp. 361-372. AOAC press.

DERRAIK, J.G.B. and SLANEY, D. 2005. The toxicity of used coffee grounds to the larvae of Ochlerotatus (Finlaya) notoscriptus (Skuse) (Diptera: Culicidae). Ann. Med. Ent. 14: 14-24.

FARHANA, K., ISLAM, H., EMRAN, E.H. and ISLAM, N. 2006. Toxicity and repellent activity of three spice materials on Tribolium castaneum (Herbst) adult. J. bio-sci. 14: 127-30

GOOD, N.E. 1933. Biology of the flour beetles, Tribolium confusum Duv. and T. ferruginaeum Fab. J. Agric. Res. 46: 327-334.

GOOD, N.E. 1936. The flour beetles of the genus Tribolium. Technical Bulletin US Dept. Agric. 5: 27-28.

GUERREIRO, F.O. and MAZZAFERA, P. 2003. Caffeine and resistance of coffee to the berry borer Hypothenemus hampei (Coleoptera: Scolytidae). J. Agric. Food Chem. 51: 6987-6991.

HEWAVITHARANAGE, P., KARUNARATNE, S. and KUMAR, N. S. 1999. Effect of caffeine on shot-hole borer beetle (Xyleborus fornicatus) of tea (Camellia sinensis). Phytochemistry 51: 35-41.

HOLLINGSWORTH, R.G., ARMSTRONG, J.W. and CAMPBELL, E. 2002. Caffeine as repellent for slugs and snails. Nature, Lond. 417: 915-916.

HOLLINGSWORTH, R.G., ARMSTRONG, J.W. and CAMPBELL, E. 2003. Caffeine as a novel toxicant for slugs and snails. Ann. Appl. Biol. 142: 91-97

ITOYAMA, M.M. and BICUDO, H.E.M.C. 1992. Effects of caffeine on fecundity, egg laying capacity, development time and longevity in Drosophila prosaltans. Rev. Bras. Genet. 15: 303-321.

ITOYAMA, M.M. and BICUDO, H.E.M.C. 1997. Effects of caffeine on mitotic index in Drosophila prosaltans (Diptera). Rev. Bras. Genet. 20: 655-658.

JILANI, G., SAXENA, R.C. and RUEDA, B.P. 1988. Repellent and growth inhibiting effects of turmeric oil, sweet flag oil, and "Margoson-O" on red flour beetle (Coleoptera: Tenebrionidae). J. Econ. ENT. 81(4): 1226-1230.

JOHNSTON, J.J. 2005. Evolution of cocoa and coffee derived methylxanthines as toxicants for the control of pest coyotes. J. Agric. Food Chem. 53: 4069-4075. 
LARANJA, A.T., MANZATTO, J. and BICUDO, H.E.M.C. 2003. Effects of caffeine and used coffee grounds on biological features of Aedes aegypti (Diptera, Culicidae) and their possible use in alternative control. Genet. Mol. Biol. 26: 419-429.

LINZ, G.M., HOMAN, H.J., SLOWIK, A. A. and PENRY, L.B. 2006. Evaluation of registered pesticides as repellent for reducing blackbird (Icteridae) damage to sunflower. Crop Prot. 25: 842-847.

MONDAL, K.A.M.S.H. and AKTAR, N. 1992. Toxicity of caffeine and castor oil to Tribolium castaneum adults and larvae (Coleoptera: Tenebrionidae). Pak. J. Zool. 24: 283-286.

MUKHERJEE, S.N. and RAMACHANDRAN, R. 1989. Effects of Azadirachtin on the feeding, growth and development of Tribolium castaneum (Herbst) (Coleoptera, Tenebrionidae). J. Appl. Ent. 10(2): 145-149.

NATHANSON, J.A. 1984. Caffeine and related Methylxanthines: Possible Naturally Occuring Pesticides. Science, New series 226(4671): 184-187.

NIGSCH, J., GRAF, U. and WURGLER, F.E. 1977. Caffeine toxicity in Drosophila strains having different mms sensitivities. Mutat. Res. 43: 57-64.

OKONKWO, E.U. and OKOYE, W.I. 1996. The efficacy of four seed powders and the essential oils as protectants of cowpea and maize grains against infestation by Callosobruchus maculatus (Fabricus) (Coleoptera: Bruchidae) and Sitophilus zeamais (Motschulsky) (Coleoptera: Curculionidae) in Nigeria. Int. J. Pest Manage. 42: 143-6.

PERIERA, J. and WOHLGEMUTH, R. 1982. Neem (Azadirachta indica, A. Juss.) of west African origin as a protectant of stored maize. Z. Ang. Ent. 24: 208-14.

PRANOTO, R. I., SIM, M.S., HOWIE, A.M.E. and HO, S.H. 1991. Grain storage Pand control practices in Singapore. In: Current Trends in Integrated pest management for Grain Storage in the ASEAN Region. (Ed., Frio, A. S.). ASEAN Grain Postharvest Programme. Thailand. pp. 67-80.

RAHMAN, M.F., KARIM, M.R., ALAM, M.J., ISLAM, M.F., HABIB, M.R., UDDIN, M.B. and HOSSAIN, M.T. 2011. Insecticidal effect of oyster mushroom (Pleurotus ostreatus) against Tribolium castaneum (Herbst), Nat Products. Ann. Ind. J. 7: 187-190.

SAGHEER, M., MANSOOR-UL-HASAN, LATIF, M.A. and IQBAL, J. 2011. Evaluation of some indigenous medicinal plants as a source of toxicant, repellent and growth inhibitors against Tribolium castaneum (Coleoptera: Tenebrionidae). Pak. J. Ent. 33: 87-91.

SAXENA, K. N. 1969. Patterns of insect-plant relationship determining susceptibility or resistance of different plants to an insects. Ent. Exp. Appl. 12: 751-766.

SENGAL, S.S., SIMOES, L.C.G. and JURAND, A. 1977. Effects of caffeine on growth and metamorphosis of moth fly Telmatoscopus albipunctatus (Diptera, Psychodidae). Entomol. Exp. Applic. 21: 174-181.

ZIEGLER, J.R. 1977. Dispersal and reproduction in Tribolium, the influence of food level. J. Insect. Physiol. 23: 955-960.

ZIMMERING, S., KOFKOFF, R. and OSGOOD, C. 1977. Survival of caffeine-feed adult males and females from strains of Drosophila melanogaster. Mutat. Res. 43: 453-456.

(Manuscript received on 25 May, 2014; revised on 21 November, 2014) 